\title{
Removal of lead, cadmium and copper ions from aqueous solutions by using ion exchange resin $\mathrm{C} 160$
}

\section{Introduction}

At the present time, the pollution of the environment by toxic metals is a major environmental problem. Among the metals, lead, cadmium, mercury and copper are particularly dangerous for living organisms. Frequently, these metal ions get into natural waters with wastes from metallurgical, chemical and electronic industries, as well as leachates from industrial and municipal wastes. The sewage from the metallurgical industry constitutes a special type of waste. This is due to its toxicity. Apart from lead, cadmium and copper also contain such elements as cobalt, nickel, zinc, chromium, silver, gold, as well as complexing agents and cyanides. Therefore, their purification is extremely difficult and costly (Kolodynska 2009).

The ion exchange process plays a significant role in modern technologies concerning the removal of metal ions from waste water. It involves replacing ions included in ion exchange resin with an equal amount of other ions of the same sign, located in the purified aqueous solution (Winnicki 1978; Granops and Kaleta 2004; Bozecka 2013).

Synthetic ion exchangers (ion exchange resins) (Winnicki 1978) play a great practical role among the wide group of ion exchangers. This is due to their unique structure which allows for the selective exchange of ions present in their backbone to the ionic form in solu-

* PhD, ** Professor, AGH University of Science and Technology, Faculty of Mining and Geoengineering, Krakow, Poland; e-mail: gala@agh.edu.pl 
tion. An important advantage of ion exchangers is also the possibility of regeneration and recovery of the removed metals. The technological usefulness of synthetic ion exchangers is identified by a number of factors, among them: particle size, bulk density, chemical resistance, selectivity, water content, exchange capacity (Bozecka et al. 2013).

Table 1. Comparison of ion exchange capabilities of synthetic resins (Bozecka 2013)

Tabela 1. Porównanie zdolności jonowymiennych syntetycznych jonitów (Bozecka 2013)

\begin{tabular}{|c|c|c|c|c|c|c|c|c|}
\hline $\begin{array}{l}\text { Metal } \\
\text { ion }\end{array}$ & $\begin{array}{l}\text { Ion } \\
\text { exchange } \\
\text { resin }\end{array}$ & $\begin{array}{c}\text { Characteristics of } \\
\text { the ion exchange } \\
\text { resin }\end{array}$ & $\begin{array}{l}\text { Dose } \\
{[\mathrm{g} / \mathrm{L}]}\end{array}$ & $\begin{array}{c}\text { The initial } \\
\text { concentration } \\
\text { of metal } \\
{[\mathrm{mg} / \mathrm{L}]}\end{array}$ & $\mathrm{pH}$ & $\begin{array}{c}\text { The maximum } \\
\text { sorption } \\
\text { capacity } \\
{[\mathrm{mg} / \mathrm{g}]}\end{array}$ & $\begin{array}{c}\text { Degree of } \\
\text { purification } \\
{[\%]}\end{array}$ & Literature \\
\hline \multirow{2}{*}{$\mathrm{Pb}^{2+}$} & $\begin{array}{l}\text { Purolite } \\
\text { C100 }\end{array}$ & \multirow{2}{*}{$\begin{array}{c}\text { Functional } \\
\text { groups }- \text { sulfonic } \\
\text { Ion form }-\mathrm{H}^{+}\end{array}$} & 25.0 & $2.7-265.0$ & n.d. & 9.6 & $\begin{array}{c}75.5 \text { (for } \\
\text { concentration } \\
2.7 \mathrm{mg} / \mathrm{L} \text { ) }\end{array}$ & $\begin{array}{l}\text { Abo-Farha } \\
\text { et al. } 2009\end{array}$ \\
\hline & $\begin{array}{l}\text { Amberlite } \\
\text { IR } 120\end{array}$ & & 5.0 & $5.0-100$ & 5.0 & 9.8 & $\begin{array}{c}98.6 \text { (for } \\
\text { concentration } \\
20 \mathrm{mg} / \mathrm{L} \text { ) }\end{array}$ & $\begin{array}{c}\text { Kocaoba } \\
2007\end{array}$ \\
\hline \multirow{3}{*}{$\mathrm{Cd}^{2+}$} & $\begin{array}{l}\text { Duolite } \\
\text { ES } 467\end{array}$ & \multirow{2}{*}{$\begin{array}{c}\text { Functional } \\
\text { groups - } \\
\text { aminophosphonic } \\
\text { Ion form }-\mathrm{Na}^{+}\end{array}$} & 10.0 & $70.0-350.0$ & 4.9 & 13.8 & n.d. & $\begin{array}{c}\text { Srinivasa et } \\
\text { al. } 2010\end{array}$ \\
\hline & $\begin{array}{l}\text { Amberlite } \\
\text { IR } 120\end{array}$ & & 2.0 & 20.0 & 5.5 & n.d. & 90.8 & \multirow{2}{*}{$\begin{array}{c}\text { Kocaoba } \\
\text { and Akcin } \\
2005\end{array}$} \\
\hline & $\begin{array}{l}\text { Amberlite } \\
\text { IR } 120\end{array}$ & $\begin{array}{l}\text { Functional } \\
\text { groups - sulfonic } \\
\text { Ion form }-\mathrm{H}^{+}\end{array}$ & 2.0 & 20.0 & 5.5 & n.d. & 81.1 & \\
\hline \multirow{4}{*}{$\mathrm{Cu}^{2+}$} & $\begin{array}{c}\text { Chelex } 100 \\
\text { Amberlite } \\
\text { IRC748 }\end{array}$ & $\begin{array}{l}\text { Macroporous } \\
\text { chelating ion } \\
\text { exchange resins } \\
\text { containing } \\
\text { iminodiacetic acid } \\
\text { (IDA) }\end{array}$ & 1.0 & $190-571$ & $2-6.5$ & n.d. & n.d. & $\begin{array}{c}\text { Lin and } \\
\text { Juang } 2007\end{array}$ \\
\hline & $\begin{array}{l}\text { Lewatit } \\
\text { TP207 } \\
\text { Lewatit } \\
\text { TP208 }\end{array}$ & $\begin{array}{l}\text { Chelating ion } \\
\text { exchangers with } \\
\text { the iminodiacetate } \\
\text { functional groups } \\
\text { (IDA) }\end{array}$ & 20.0 & 6.35 & $1-7$ & n.d. & $\begin{array}{l}44.8-\mathrm{pH}=1 \\
99.0-\mathrm{pH}=7\end{array}$ & $\begin{array}{l}\text { Rudnicki } \\
\text { et al. } 2014\end{array}$ \\
\hline & $\begin{array}{c}2.4- \\
\text { DHBEDF }\end{array}$ & $\begin{array}{c}\text { Chelating } \\
\text { copolymer resin }\end{array}$ & 1.0 & n.d. & 4.5 & n.d. & n.d. & $\begin{array}{c}\text { Gurnule } \\
\text { and Dhote } \\
2012\end{array}$ \\
\hline & $\begin{array}{l}\text { Lewatit } \\
\text { TP207 }\end{array}$ & $\begin{array}{l}\text { Chelating ion } \\
\text { exchanger } \\
\text { resin with the } \\
\text { iminodiacetate } \\
\text { functional groups } \\
\text { (IDA) }\end{array}$ & n.d. & $0.5-14$ & $7.3-7.6$ & n.d. & 99 & $\begin{array}{l}\text { Korngold } \\
\text { et al. } 1996\end{array}$ \\
\hline
\end{tabular}

n.d. - no data 
The use of ion exchange resins for the removal of toxic metals such as: lead, cadmium and copper from water and waste water is the subject of many scientific studies (Korngold et al. 1996; Rengaraj et al. 2001; Sanak-Rydlewska and Zięba 2001; Kocaoba and Akcin 2005; Kocaoba 2007; Lin and Juang 2007; Abo-Farha et al. 2009; Srinivasa et al. 2010; Gurnule and Dhote 2012; Rudnicki et al. 2014). The results of the studies of these teams are summarized in Table 1.

The aim of this study was to determine and compare the sorption properties of synthetic resin $\mathrm{C} 160$ towards $\mathrm{Pb}^{2+}, \mathrm{Cd}^{2+}$ and $\mathrm{Cu}^{2+}$ ions. The results obtained for $\mathrm{Cd}^{2+}$ and $\mathrm{Cu}^{2+}$ ions were compared with results obtained for $\mathrm{Pb}^{2+}$ ions which were published before (Bozecka et al. 2013; Bozecka et al. 2014).

\section{Experimental methods}

The subject of the research was $\mathrm{C} 160$ ion-exchange resin produced by Purolite. It is a strongly acidic cation-exchange resin with sulfonic acid groups $\left(-\mathrm{SO}_{3} \mathrm{H}\right)$. The applied synthetic ion exchange resin worked in a sodium cycle. A crucial step in the preparation of the resin for this research was swelling in deionized water for 24 hours.

For the purpose of the research test, a $0.5 \mathrm{~g}$ sample of the ion exchange resin was used. The range of the studied initial concentration of the $\mathrm{Pb}^{2+}, \mathrm{Cd}^{2+}$ and $\mathrm{Cu}^{2+}$ ions in solutions was from $6.25 \mathrm{mg} / \mathrm{L}$ to $109.39 \mathrm{mg} / \mathrm{L}$. The metal ions were introduced into the solution in the form of nitrates $(\mathrm{V})$. All experiments were performed at a fixed $\mathrm{pH}$ value and at an ionic strength equal to $0.02 \mathrm{~mol} / \mathrm{L}$. Its value was adjusted using a $\mathrm{KNO}_{3}$ solution at the concentration of $0.04 \mathrm{~mol} / \mathrm{L}$. The $\mathrm{pH}$ of the solution was equal to $4.0( \pm 0.1)$. For $\mathrm{pH}$ adjustment $0.02 \mathrm{M} \mathrm{HNO}_{3}$ was used. The applied experimental conditions were established according to the previous studies (Bozecka 2013).

The ion exchange processes were performed using a mechanical stirrer. For this purpose, $100 \mathrm{~L}$ of solutions with ion exchange resin were placed in a beaker which was then placed in a thermostatic bath at a constant temperature of $298 \pm 0.5 \mathrm{~K}$ for 15 minutes. The contents of the beakers were continuously stirred for 60 minutes with the speed of $120 \mathrm{rpm}$. Samples used for analysis were collected after one hour of reaction, because after that time the system reached equilibrium. This was based on the experiments that were developed for natural sorbents (Bozecka 2013).

The final concentration of $\mathrm{Pb}^{2+}$ and $\mathrm{Cd}^{2+}$ ions in the solutions after the ion exchange process was determined by the flow-through coulometry using an EcaFlow 150 GLP device manufactured by POL-EKO. Before measurements, the solutions were filtered using filter paper to remove solid particles. Three measurements were performed for each sample. Equilibrium concentration values indicated in this paper are the arithmetic averages of three measurements.

In the case of $\mathrm{Cu}^{2+}$ ions, the final concentration in the solutions was determined using the kuprizon's method with UV-VIS spectroscopy. Assays were carried out in an ammonia- 
-citrate medium at $\mathrm{pH} 8.0-9.5$. The absorbance of the solution was measured at a wavelength of $600 \mathrm{~nm}$.

The degree of purification of the solutions for $\mathrm{Pb}^{2+}, \mathrm{Cd}^{2+}$ and $\mathrm{Cu}^{2+}$ ions, $X(\%)$, were calculated using formula (1):

$$
X=\frac{c_{o}-c_{e q}}{c_{o}} \cdot 100 \%
$$

$\Leftrightarrow c_{o}$ and $c_{e q}-$ are the initial and equilibrium concentrations of the studied ions in solutions $[\mathrm{mg} / \mathrm{L}]$.

The sorption capacity, $Q[\mathrm{mg} / \mathrm{g}]$, was determined as the amount of $\mathrm{Pb}^{2+}, \mathrm{Cd}^{2+}$ and $\mathrm{Cu}^{2+}$ ions contained in the dry weight of ion-exchange resin according to the concentration in the aqueous solution, according to formula (2):

$$
Q=\frac{V\left(c_{o}-c_{e q}\right)}{m}
$$

$\Leftrightarrow V \quad-\quad$ is the volume of the solution [L],

$c_{o}$ and $c_{e q}-$ are the initial and equilibrium concentrations of studied ions in the solution $[\mathrm{mg} / \mathrm{L}]$,

$m$

- is the quantity of dry mass of the ion-exchange resin $[\mathrm{g}]$.

\section{Discussion of the results}

\subsection{Influence of the concentration of studied ions on their removal using ion-exchange resin $\mathrm{C} 160$}

The determined degree of purification of the solutions for $\mathrm{Pb}^{2+}, \mathrm{Cd}^{2+}$ and $\mathrm{Cu}^{2+}$ ions using ion exchanger resin C 160 as a function of the initial concentration are shown graphically in Figs. $1-3$ and summarized in Table 2.

The obtained results show that at the studied concentrations, the $\mathrm{C} 160$ ion exchange resin effectively removes $\mathrm{Pb}^{2+}, \mathrm{Cd}^{2+}$ and $\mathrm{Cu}^{2+}$ ions from aqueous solutions. The greatest degree of purification of the solutions was achieved for lead. They amounted to, respectively, $99.8 \%$ and $99.9 \%$ (Table 2).In the entire range of the studied concentrations of lead ions, the efficiency of the process is practically constant. For other solutions, the ion exchange process occurs with lower efficiency but also reaches more than $90 \%$. 


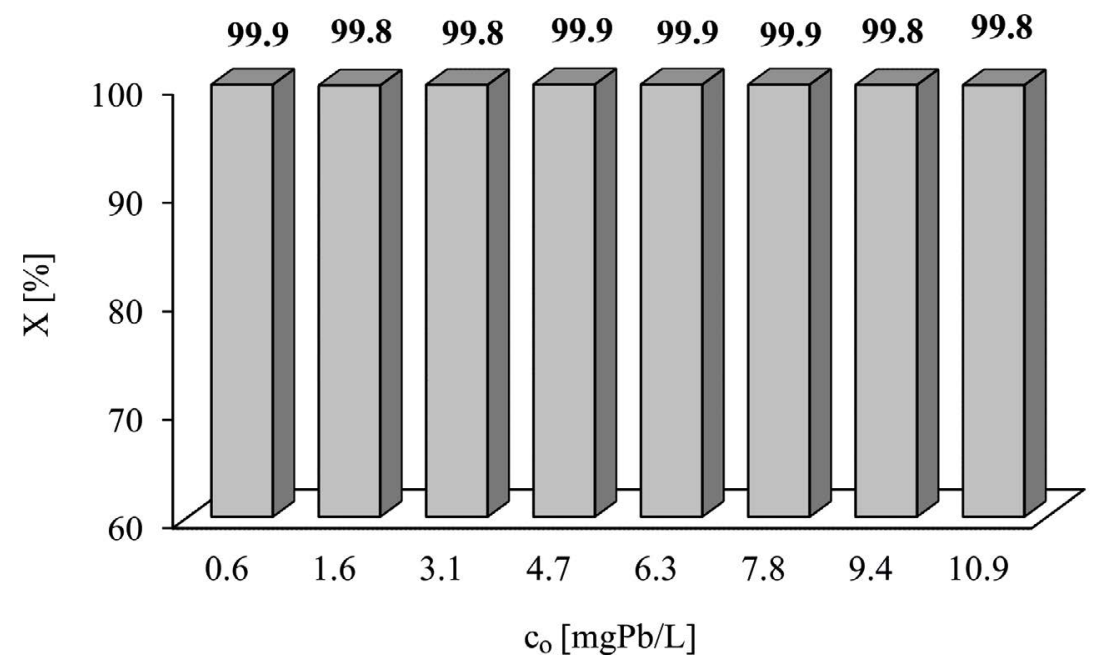

Fig. 1. Influence of the initial concentration of solutions on ion exchange of $\mathrm{Pb}^{2+}$ ions using ion exchange resin C 160 (weight of ion exchange resin $0.5 \mathrm{~g}$; ionic strength $0.02 \mathrm{~mol} / \mathrm{L}$; $\mathrm{pH} 4.0 \pm 0.1$; temperature $(298 \pm 0.5) \mathrm{K}$; time of adsorption $1 \mathrm{~h}$; mixing speed $120 \mathrm{rpm}$.)

Rys. 1. Wpływ stężenia wyjściowego roztworów na proces wymiany jonowej jonów $\mathrm{Pb}^{2+}$ na jonicie $\mathrm{C} 160$ (masa jonitu $0,5 \mathrm{~g}$; siła jonowa $0,02 \mathrm{~mol} / \mathrm{dm}^{3}$; $\mathrm{pH} 4.0 \pm 0.1$; temp. $(298 \pm 0,5) \mathrm{K}$; czas $1 \mathrm{~h}$; szybkość mieszania 120 obrotów/min.)

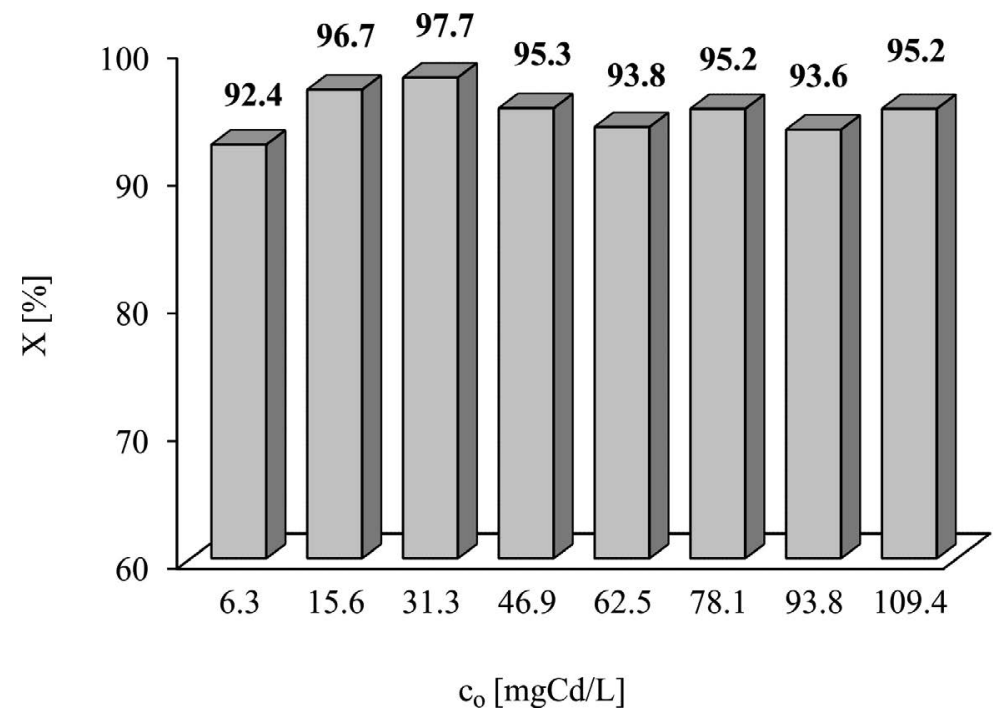

Fig. 2. Influence of the initial concentration of solutions on ion exchange of $\mathrm{Cd}^{2+}$ ions for ion exchange resin C 160 (weight of ion exchange resin $0.5 \mathrm{~g}$; ionic strength of $0.02 \mathrm{~mol} / \mathrm{L}$; $\mathrm{pH} 4.0 \pm 0.1$; temperature $(298 \pm 0.5) \mathrm{K}$; time of adsorption $1 \mathrm{~h}$; mixing speed $120 \mathrm{rpm}$.)

Rys. 2. Wpływ stężenia wyjściowego roztworów na proces wymiany jonowej jonów $\mathrm{Cd}^{2+}$ na jonicie $\mathrm{C} 160$

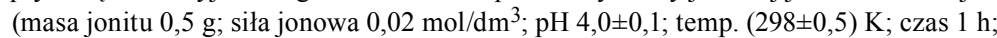
szybkość mieszania 120 obrotów/min.) 


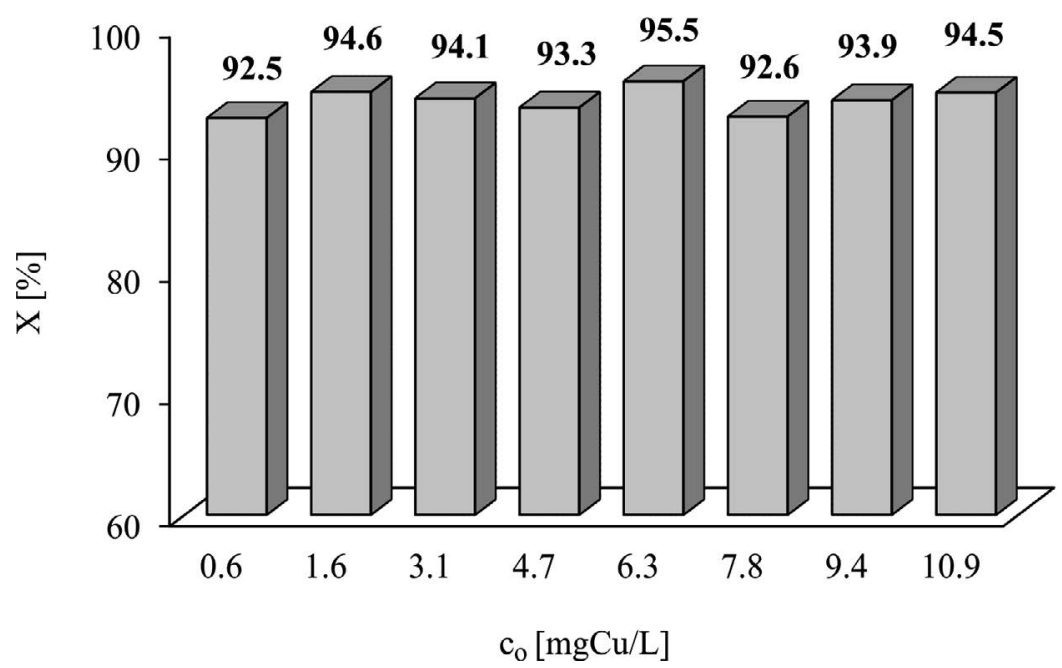

Fig. 3. Influence of the initial concentration of solutions on ion exchange of $\mathrm{Cu}^{2+}$ ions for ion exchange resin $\mathrm{C}$ 160 (weight of ion exchange resin $0.5 \mathrm{~g}$; ionic strength of $0.02 \mathrm{~mol} / \mathrm{L} ; \mathrm{pH} 4.0 \pm 0.1$; temperature $(298 \pm 0.5) \mathrm{K}$; time of adsorption $1 \mathrm{~h}$; mixing speed $120 \mathrm{rpm}$.)

Rys. 3. Wpływ stężenia wyjściowego roztworów na proces wymiany jonowej jonów $\mathrm{Cu}^{2+}$ na jonicie $\mathrm{C} 160$

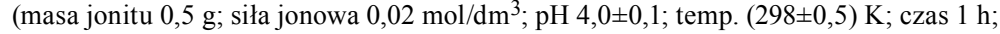
szybkość mieszania 120 obrotów/min.)

Table 2. Dependence of the degree of purification of the solutions as a function of the initial concentration of $\mathrm{Pb}^{2+}, \mathrm{Cd}^{2+}$ and $\mathrm{Cu}^{2+}$ ions in the solution for studied ion exchange resin $\mathrm{C} 160$

Tabela 2. Zależność stopnia oczyszczenia roztworów w funkcji stężenia wyjściowego jonów $\mathrm{Pb}^{2+}, \mathrm{Cd}^{2+} \mathrm{i} \mathrm{Cu}^{2+}$ dla badanego jonitu C 160

\begin{tabular}{|c|c|c|c|}
\hline \multirow{2}{*}{$\begin{array}{c}\text { Initial concentrations of metal } \\
c_{o}[\mathrm{mg} / \mathrm{L}]\end{array}$} & \multicolumn{3}{|c|}{ Degree of purification [\%] } \\
\cline { 2 - 4 } & $\mathrm{Pb}^{2+}$ & $\mathrm{Cd}^{2+}$ & $\mathrm{Cu}^{2+}$ \\
\hline 6.25 & 99.87 & 92.43 & 92.45 \\
\hline 15.65 & 99.80 & 96.74 & 94.58 \\
\hline 31.30 & 99.85 & 97.70 & 94.07 \\
\hline 46.95 & 99.89 & 95.29 & 93.31 \\
\hline 62.60 & 99.88 & 93.81 & 95.46 \\
\hline 78.25 & 99.87 & 95.24 & 92.57 \\
\hline 93.90 & 99.84 & 93.60 & 93.91 \\
\hline 109.55 & 99.82 & 95.24 & 94.53 \\
\hline
\end{tabular}


It was observed that with the increasing concentration of $\mathrm{Cd}^{2+}$ ions in the solution, the efficiency of the investigated process decreases. The $\mathrm{Cu}^{2+}$ ions behave similarly.

Interpretation of the results of sorption of studied ions based on the Langmuir adsorption model

The removal of $\mathrm{Pb}^{2+}, \mathrm{Cd}^{2+}$ and $\mathrm{Cu}^{2+}$ ions using ion exchange resin $\mathrm{C} 160$ was described using the Langmuir isotherm. The characteristics of this model are given in Table 3.

The results of the study approximated with the Langmuir equations were shown in Fig. 4.

Table 3. Characteristics of the Langmuir model (Bozecka 2013)

Tabela 3. Charakterystyka modelu Langmuira (Bozecka 2013)

\begin{tabular}{|c|c|c|}
\hline \multicolumn{3}{|c|}{ The Langmuir isotherm } \\
\hline Assumptions & \multicolumn{2}{|l|}{$\begin{array}{l}\text { there is a specified number of adsorption centers on the adsorbent surface } \\
\text { and each of them is able to adsorb only one molecule } \\
\text { energy state of each of the adsorbed individual is the same in all places on the surface } \\
\text { of the adsorbent. } \\
\text { localized adsorption takes place which means that particles cannot move freely on the surface. } \\
\text { Lateral interactions between the adsorbed molecules are irrelevant. }\end{array}$} \\
\hline Equation & $Q=\frac{q_{\max } b \cdot c_{e q}}{\left(1+b \cdot c_{e q}\right)}$ & (3) \\
\hline $\begin{array}{l}\text { The linear } \\
\text { form, where }\end{array}$ & $\begin{array}{l}\qquad \frac{1}{Q}=\frac{1}{q_{\max } b} \cdot\left(\frac{1}{c_{e q}}+b\right) \\
Q-\text { amount of the metal ions adsorbed per weight unit of the ion exchanger }[\mathrm{mg} / \mathrm{g}] \\
c_{e q}-\text { the final concentrations of metal ions in solution }[\mathrm{mg} / \mathrm{L}] \\
q_{\max }[\mathrm{mg} / \mathrm{g}] \text { and } b[\mathrm{~L} / \mathrm{mg}] \text { are Langmuir constants }\end{array}$ & (4) \\
\hline
\end{tabular}

Table 4. The Langmuir isotherms coefficients with their uncertainty and correlation coefficient for $\mathrm{Pb}^{2+}, \mathrm{Cd}^{2+}$ and $\mathrm{Cu}^{2+}$ ions adsorbed on ion exchange resin $\mathrm{C} 160$

Tabela 4. Współczynniki izoterm Langmuira wraz z niepewnościami i współczynniki korelacji otrzymane dla jonów $\mathrm{Pb}^{2+}, \mathrm{Cd}^{2+} \mathrm{i} \mathrm{Cu}^{2+}$ na jonicie $\mathrm{C} 160$

\begin{tabular}{|c|c|c|c|c|c|}
\hline Studied ion & $\begin{array}{c}q_{\max } \\
{[\mathrm{mg} / \mathrm{g}]}\end{array}$ & $\begin{array}{c}\Delta \mathrm{q}_{\max } \\
{[\mathrm{mg} / \mathrm{g}]}\end{array}$ & $\begin{array}{c}b \\
{[\mathrm{~L} / \mathrm{mg}]}\end{array}$ & $\begin{array}{c}\Delta b \\
{[\mathrm{~L} / \mathrm{mg}]}\end{array}$ & $R$ \\
\hline $\mathrm{Pb}^{2+}$ & 112.17 & 2.19 & 1.4370 & 0.00200 & 0.9878 \\
\hline $\mathrm{Cd}^{2+}$ & 31.76 & 0.69 & 0.2348 & 0.00020 & 0.8282 \\
\hline $\mathrm{Cu}^{2+}$ & 468.42 & 9.35 & 0.0071 & 0.00001 & 0.9856 \\
\hline
\end{tabular}




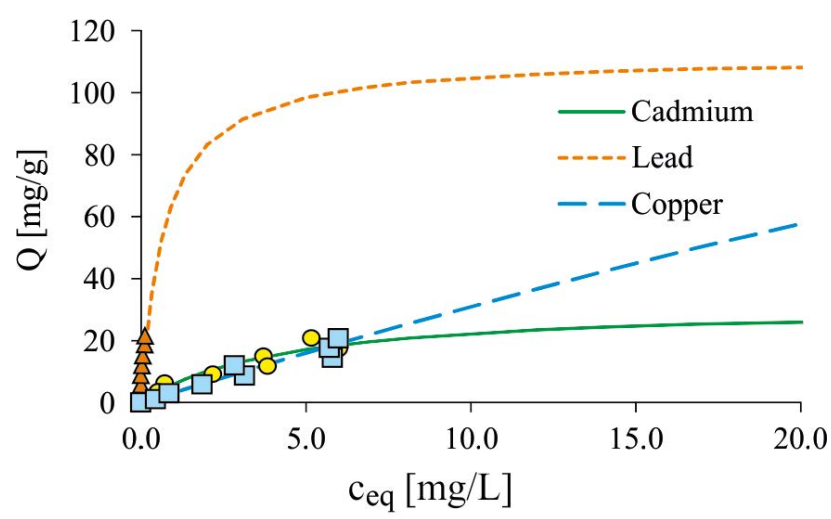

Fig. 4. A comparison of the Langmuir isotherms of $\mathrm{Pb}^{2+}, \mathrm{Cd}^{2+}$ and $\mathrm{Cu}^{2+}$ ions for ion exchange resin $\mathrm{C} 160$ (weight of ion exchange resin $0.5 \mathrm{~g}$; ionic strength of $0.02 \mathrm{~mol} / \mathrm{L} ; \mathrm{pH} 4.0 \pm 0.1$; time of adsorption $1 \mathrm{~h}$; mixing speed $120 \mathrm{rpm}$.)

Rys. 4. Porównanie izoterm Langmuira jonów $\mathrm{Pb}^{2+} \mathrm{Cd}^{2+} \mathrm{i} \mathrm{Cu}^{2+}$ na jonicie $\mathrm{C} 160$ (masa jonitu $0,5 \mathrm{~g}$; siła jonowa $0,02 \mathrm{~mol} / \mathrm{dm}^{3} ; \mathrm{pH} \mathrm{4,0 \pm 0,1;} \mathrm{czas} 1 \mathrm{~h}$; szybkość mieszania 120 obrotów/minutę)

The values of coefficient $q_{\max }$ and $b$ in the Langmuir isotherms were determined on the basis of the linear form (Table 3). The values of these coefficients with uncertainties and the correlation coefficient $R$ are presented in Table 4.

According to the data presented on Figure 4, for each of studied ions, sorption capacity increases until the saturation and equilibrium state is reached. The highest value of constant $q_{\max }$ was obtained in the case of $\mathrm{Cu}^{2+}$ ions. It was $468.42 \mathrm{mg} / \mathrm{g}$. For other ions, respectively, the $q_{\text {max }}$ parameter reached: $\mathrm{Pb}^{2+} 112.17 \mathrm{mg} / \mathrm{g}$ and $\mathrm{Cd}^{2+} 31.76 \mathrm{mg} / \mathrm{g}$ values (Table 4). Ion exchange resin $\mathrm{C} 160$ shows the highest affinity for the $\mathrm{Pb}^{2+}$ ions. In this case, the value of coefficient $b$ was $1.437 \mathrm{~L} / \mathrm{mg}$. For other ions, the obtained value were equal $0.2348 \mathrm{~L} / \mathrm{mg}$ (for $\mathrm{Cd}^{2+}$ ions) and $0.0071 \mathrm{~L} / \mathrm{mg}$ (for $\mathrm{Cu}^{2+}$ ions) (Table 4).

\section{Conclusion}

On the basis of this study the following conclusions can be drawn:

- C 160 is an effective ion exchange resin for the studied divalent metal ions such as: $\mathrm{Cu}, \mathrm{Pb}$ and $\mathrm{Cd}$;

- for the studied concentration range, the highest degree of purification of the solutions from the above-mentioned ions ranged from approximately $92 \%$ to over $99 \%$ (Table 2);

- the greatest degree of separation was observed for the lead ions, reaching over $99 \%$ in the range of the studied concentrations (Table 2 and Figure 1); 
- based on the interpretation of the Langmuir equation coefficients, an indication can be made that the studied ion exchange resin has a major sorption capacities toward copper ions ( $q_{\max }$ constant value was approximately $468.42 \mathrm{mg} / \mathrm{g}$ ) (Table 4$)$;

- the highest affinity (value of parameter b) ion exchange resin C 160 reached was for lead ions and it was approximately $1.44 \mathrm{~L} / \mathrm{mg}$ (Table 4).

The study was carried out as part of the AGH research programme number 11.11.100.196.

\section{LITERATURE}

Abo-Farha et al. 2009 - Abo-Farha, S.A., Abdel-Aal, A.Y., Ashour, I.A. and Garamon, S.E. 2009. Removal of some heavy metal cations by synthetic resin purolite C100. Journal of Hazardous Materials 169, pp. 190-194.

Bożęcka, A. 2013. Usuwanie jonów metali toksycznych z roztworów wodnych za pomoca odpadów organicznych Doctoral Dissertation AGH (in Polish).

Bożęcka et al. 2013 - Bożęcka, A., Bożęcki, P., Kasprzyk, P. and Sanak-Rydlewska, S. 2013. Usuwanie jonów ołowiu(II) z modelowych roztworów wodnych metodą wymiany jonowej. Inżynieria i Aparatura Chemiczna 52/3, pp. 152-154 (in Polish).

Bożęcka et al. 2014 - Bożęcka, A., Bożęcki, P., Kasprzyk, P. and Sanak-Rydlewska, S. 2014. Usuwanie jonów ołowiu z roztworów wodnych za pomocą sorbentów naturalnych i żywic jonowymiennych [W:] Klich, A., Kozieł, A. red. Innowacyjne i przyjazne dla środowiska techniki i technologie przeróbki surowców mineralnych: bezpieczeństwo - jakość - efektywność. Instytut Techniki Górniczej, pp. 353-368 (in Polish).

Granops, M. and Kaleta, J. 2004. Technologia wody. Laboratorium. Rzeszów: Oficyna Wydawnicza Politechniki Rzeszowskiej (in Polish).

Gurnule, W.B. and Dhote, S.S. 2012. Preparation, Characterization and Chelating Ion-exchange Properties of copolymer Resin Derived from 2,4-Dihydroxy Benzoic acid, Ethylene Diamine and Formaldehyde. Der Pharma Chemica 4, pp. 791-799.

Kocaoba, S. and Akcin, G. 2005. Removal of chromium(III) and cadmium(II) from aqueous solutions. Desalination 180 , pp. $151-156$

Kocaoba, S. 2007. Comparison of Amberlite IR 120 and dolomite's performances for removal of heavy metals. Journal of Hazardous Materials 147, pp. 488-496.

Kołodyńska, D. 2009. Żywice chelatujące w procesie usuwania jonów metali ciężkich w obecności czynnika kompleksującego z wód i ścieków, Przemyst Chemiczny 88/2, pp. 182-189 (in Polish).

Korngold et al. 1996 - Korngold, E., Belfer, S. and Urtizberea, C., 1996. Removal of heavy metals from tap water by a cation Exchange, Desalination 104, pp. 197-201.

Lin, L.-Ch. and Juang, R.-S. 2007. Ion-exchange kinetics of $\mathrm{Cu}(\mathrm{II})$ and $\mathrm{Zn}$ (II) from aqueous solutions with two chelating resins. Chemical Engineering Journal 132, pp. 205-213.

Rengaraj et al. 2001 - Rengaraj, S., Yeon, K.H. and Moon, S.H. 2001. Removal of chromium from water and wastewater by ion exchange resins. Journal of Hazardous Materials B87, pp. 273-287.

Rudnicki et al. 2014 - Rudnicki, P., Hubicki, Z., Kołodyńska, D. 2014. Evaluation of heavy metal ions removal from acidic waste water streams. Chemical Engineering Journal 252, pp. 362-373.

Sanak-Rydlewska, S. and Zięba, D. 2001. Badania nad zastosowaniem wymieniaczy jonowych do usuwania Cu i $\mathrm{Pb}$ z potrawiennych roztworów odpadowych. Gospodarka Surowcami Mineralnymi - Mineral Recourses Management t. 17, pp. 229-239 (in Polish).

Srinivasa et al. 2010 - Srinivasa Rao, K., Roy Chaudhury, G. and Mishra, B.K. 2010. Kinetics and equilibrium studies for the removal of cadmium ions from aqueous solutions using Duolite ES 467 resin. International Journal of Mineral Processing 97, pp. 68-73.

Winnicki, T. 1978. Polimery czynne w inżynierii ochrony środowiska. Warszawa: Wyd. Arkady (in Polish). 


\title{
USUWANIE JONÓW OLOWIU, KADMU I MIEDZI Z ROZTWORÓW WODNYCH ZA POMOCA ŻYWICY JONOWYMIENNEJ C 160
}

\author{
Słowa kluczowe \\ jonity, wymiana jonowa, jony ołowiu, kadmu, miedzi
}

\section{Streszczenie}

Roztwory odpadowe zawierające m.in. jony metali $\mathrm{Pb}, \mathrm{Cu}, \mathrm{Cd}$ i inne powstają w przemyśle elektrochemicznej obróbki metali, w przemyśle przeróbki rud metali nieżelaznych, a także mogą być składnikiem odcieków ze składowisk odpadów tych rud. Toksyczność jonowych form tych metali jest znaczna, stąd w pracy podano wyniki badań jednego ze sposobów obniżenia ich koncentracji w roztworach wodnych.

$\mathrm{W}$ artykule podano wyniki badań dotyczących usuwania jonów $\mathrm{Pb}^{2+}, \mathrm{Cd}^{2+} \mathrm{i} \mathrm{Cu}^{2+} \mathrm{z}$ modelowych roztworów wodnych za pomocą syntetycznej żywicy jonowymiennej C 160 firmy Purolite. Badany jonit zawiera w swojej strukturze grupy sulfonowe $\left(-\mathrm{SO}_{3} \mathrm{H}\right)$ i należy do silnie kwaśnych kationitów. Zakres badanych stężeń początkowych jonów $\mathrm{Pb}^{2+}, \mathrm{Cd}^{2+} \mathrm{i} \mathrm{Cu}^{2+}$ w roztworach wynosił od $6,25 \mathrm{mg} / \mathrm{dm}^{3}$ do $109,38 \mathrm{mg} / \mathrm{dm}^{3}$. Otrzymane wyniki potwierdziły, że wykorzystana żywica jonowymienna C160 skutecznie usuwa wymienione jony z badanych roztworów. Dla przyjętego zakresu stężeń i warunków procesu wymiany jonowej, największy stopień oczyszczenia roztworów osiągnięto dla ołowiu. Wynosił on $99,9 \%$. W przypadku pozostałych roztworów wymiana jonowa zachodzi z wydajnością niższą, ale wysoką i wynosi dla wszystkich jonów ponad 90\%. Wyniki badań zinterpretowano opierając się na modelu adsorpcji Langmuira. Dla każdego badanego jonu pojemność sorpcyjna jonitu wzrasta, aż do osiągnięcia wysycenia i stanu równowagi. Z interpretacji współczynników równania Langmuira wynika, że badany jonit charakteryzuje się największymi zdolnościami sorpcyjnymi w stosunku do jonów miedzi. W ich przypadku otrzymano największą wartość stałej $q_{\max }$ izotermy Langmuira. Dla jonów $\mathrm{Cu}^{2+}$ wyniosła ona $468,42 \mathrm{mg} / \mathrm{g}$. Dla jonów $\mathrm{Pb}^{2+} \mathrm{i} \mathrm{Cd}^{2+}$ parametr ten przyjął odpowiednio wartości 112,17 mg/g i 31,76 mg/g. Jonit C160 wykazuje największe powinowactwo w stosunku do jonów $\mathrm{Pb}^{2+}$. W tym przypadku otrzymana wartość współczynnika $b$ jest największa i równa $1,437 \mathrm{dm}^{3} / \mathrm{mg}$.

\section{REMOVAL OF LEAD, CADMIUM AND COPPER IONS FROM AQUEOUS SOLUTIONS BY USING ION EXCHANGE RESIN C 160}

$$
\text { Keywords }
$$

ion exchange resins, ion exchange, lead, cadmium, copper ions

$$
\text { Abstract }
$$

Industrial waste solutions may contain toxic $\mathrm{Pb}, \mathrm{Cu}, \mathrm{Cd}$ and other metal ions. These ions may also be components of leachates in landfills of ores. The toxicity of the ionic forms of these metals is high. 
For this reason the paper presents the results of studies on one of the methods to reduce their concentration in aqueous solutions. The article presents the results of studies on the removal of $\mathrm{Pb}^{2+}, \mathrm{Cd}^{2+}$ and $\mathrm{Cu}^{2+}$ ions from model aqueous solutions with synthetic ion exchange resin $\mathrm{C} 160$ produced by Purolite. The investigated ion exchanger contains sulfonic acid groups $\left(-\mathrm{SO}_{3} \mathrm{H}\right)$ in its structure and is a strongly acidic cation-exchange resin. The range of the studied initial concentrations of the $\mathrm{Pb}^{2+}$, $\mathrm{Cd}^{2+}$ and $\mathrm{Cu}^{2+}$ ions in the solutions was from $6.25 \mathrm{mg} / \mathrm{L}$ to $109.39 \mathrm{mg} / \mathrm{L}$. The results confirmed that the used ion exchange resin C160 efficiently removes the above-mentioned ions from the studied solutions. The highest degree of purification was achieved in lead solutions for the assumed range of concentrations and conditions of the ion exchange process. It reached $99.9 \%$. In the case of other solutions, the ion exchange process occurs with lower efficiency, however it remains high and amounts to over $90 \%$ for all the ions. The results of research were interpreted on the basis of the Langmuir adsorption model. For each studied ion, sorption capacity of the ion exchange resin increases until the saturation and equilibrium state is reached. Based on the interpretation of the Langmuir equation coefficients, an indication can be made that the studied ion exchange resin has a major sorption capacity towards the copper ions. In their case, the highest value of constant $q_{\max }$ was obtained in the Langmuir isotherm. For $\mathrm{Cu}^{2+}$ ions it was $468.42 \mathrm{mg} / \mathrm{g}$. For $\mathrm{Pb}^{2+}$ and $\mathrm{Cd}^{2+}$ ions, this parameter reached the values of $112.17 \mathrm{mg} / \mathrm{g}$ and $31.76 \mathrm{mg} / \mathrm{g}$, respectively. Ion exchange resin C 160 shows the highest affinity for the $\mathrm{Pb}^{2+}$ ions. In this case, the achieved value of coefficient $b$ is highest and equals $1.437 \mathrm{~L} / \mathrm{mg}$. 
